conducted by unions of local education authorities throughout Great Britain.

Whether such groups of unions will, in fact, do all the report expects, is not a matter upon which any pronouncement can be made now. From the recommendations made, however, it may be possible that ultimately a more ideal system can be built. It is a pity that, in the report itself, no mention was made of the future possibilities when the obstacles to the excellent principles of Circular 776 will be swept away. If examination, as the report wisely shows, is an educational function, hope still stays with the idealist : for in education " nothing is constant but change."

\section{Origin and Structure of the Viviparidæ.}

TWO exceedingly important papers by Dr. Baini Prashad have appeared, nominally concerned only with the Viviparidæ, but in reality covering far wider ground (Mem. Indian Mus., vol. 8).

The first deals with the recent and fossil Viviparidæ and constitutes a study in distribution, evolution, and palæogeography. The author attempts to determine the taxonomy of the family, the dispersal of which he considers to have taken place along the freshwater streams. The ordinary zoogeographical regions are of no value for the Viviparidæ, which are, therefore, considered here according to the continents and countries in which they are found, a sketch map being appended. The fossil members are treated on similar lines and genealogical trees given. The various sculptured forms are held to have been independently evolved in the different regions, and their palæogeography is discussed so far as it has a bearing on the subject in hand.

Setting aside Garwood's Viviparus carbonarius, for reasons which some will consider insufficient, the author holds that the Viviparidæ arose from the common stem of the families Trochidæ and Turbinidæ in the early Jurassic period, not, however, from a common ancestral form, but polyphyletically, taking to freshwater life in at least four regions, namely, western Europe, North America, peninsular India, and Australia. The probable time of origin in each area, the evolution of the different subgenera, and the lines of migration are then discussed.

Dr. Prashad's second paper, "On the Mantle and Shell of the Viviparidæ," was undertaken in continuation of the work of his late chief, Dr. T. N. Annandale, on the problem of the shell sculpture in the family. After a preliminary historical sketch of the relation between the shell and the animal in Gastropoda, the author passes to a detailed study of the mantle of the Viviparidæ, the important difference of which, contrasted with that of other gastropods, lies in the development of special processes on the mantle margin of the embryos, some of which also persist in the adults. There are three primary and a number of secondary and tertiary processes which correspond to the ridges or sculpture on the shells. The section dealing with the shell is in matter of fact an able summary of all that is known concerning the structure and formation of gastropod shells as a whole and should be overlooked by no malacologist.

The paper concludes with a "Review of the Literature on the Embryonic Shell-gland and Associated Structures in Mollusca," and a bibliography. The plates, five in all, are excellent specimens of photolithography, and the whole work (pp. 167) reflects the greatest credit on those responsible for its production, including the Zoological Survey of India, which in a sense is the parent of it.

\section{University and Educational Intelligence.}

Cambridge.-Mr. C. Warburton, Christ's College, has been re-appointed demonstrator in medical entomology. Miss A. S. Dale, Newnham College, has been elected to the Michael Foster research studentship in physiology. Mr. H. J. Pfister, of the University of Birmingham, has been nominated to use the University's table at the Zoological station at Naples for one month.

LoNDON.-The new statutes have been submitted to His Majesty in Council. Eight weeks from the commencement of term will be allowed for petitions. We understand that a petition has been presented by a member of Convocation for the disallowance of certain statutes nullifying or restricting the privileges of Convocation in relation to the appointment of its clerk and the approval of new statutes. The same petition objects to the exclusion of the Royal College of Science, London, from the list of Schools of the University in the Faculty of Science, on the ground that the College became a School of the University in the Faculty of Science under the statutes of 1900 and has not lost that status. The statutes were sealed by the Commissioners on July 23 , 1928.

OxFORD.-On Tuesday, Oct. 23, Congregation had two measures before it, both of which raised questions of interest to scientific men. By the first of these it was proposed to curtail the present permission of research students in letters or science to reckon periods of residence in vacation towards their statutable terms for the degrees B.Litt. or B.Sc. respectively. It was pointed out by Prof. E. B.Poulton that the opportunities for the requisite study were at least as open in vacation as in term, and that the effect of the proposed statute might well be to put great difficulty in the way, for example, of aspirants to the science degree domiciled in distant countries and with limited periods of leave. The preamble was rejected by 88 votes to 80 .

The second, a decree supported by the Provost of Worcester and Dr. J. Wells, and opposed by Sir Harold Hartley and Mr. A. H. Smith, proposed the acceptance of a generous gift of $£ 10,000$ by Prof. Joseph Wright towards the cost of extending the Taylorian Institution along the front of St. Giles's. Ungracious as it seemed to decline so munificent an offer, it was felt that the conditions attached to the gift were not in the best interest of the institution concerned, nor ultimately in that of the University. The question of provision for the future housing and extension of the Ashmolean collections, of unique scientific and archæological value, is involved; and it appeared to the majority that a more considered and wider scheme was called for than that recommended by Council. The decree failed to pass, there being 92 votes for it and 121 against.

An equally liberal gift of $£ 10,000$ from Capt. Brynar Owen and Mr. W. J. Mallinson for the purpose of engineering research in connexion with the Institute of Agricultural Engineering was gratefully accepted.

THE Institution of Chemical Engineers announces that application forms and particulars of the associatemembership examination for 1929, together with a memorandum on "The Training of a Chemical Engineer," may be had from the Honorary Registrar of the Institution, Abbey House, Westminster, S.W.1. The application forms referred to must be returned by Dec. 15.

No. 3079, VoL. 122] 